\title{
Strategies in Translating Minangkabau Cultural Words in The Land of Five Towers 'Negeri Lima Menara', Fuadi's Novel
}

\author{
Erlina Zulkifli Mahmud \\ Universitas Padjajaran \\ Bandung, Indonesia \\ erlina@unpad.ac.id
}

\begin{abstract}
This paper aims to discuss the translation of Minangkabau cultural words in Fuadi's novel The Land of Five Towers 'Negeri Lima Menara' viewed by Baker's translation strategies. Baker's strategies are used as these strategies are categorized as strategies used by professional translators for the case of non-equivalence cultural word and The Land of Five Towers 'Negeri Lima Menara' is used because the theme of the novel is about the life in pesantren, an Islamic boarding school, yet interestingly the information about Minangkabau culture decorates the story from the beginning till the end. This involves the occurrence of Minangkabau cultural words, either those which have direct equivalence in the target language text or those which do not have direct equivalence or non-equivalence. This research focuses on the non-equivalence only. By using qualitative research method, all Minangkabau cultural words in the source language text are collected and then are identified based on the availability of their equivalences. Those which have no direct equivalences are taken as the object of this research. Each word is identified based on the category of cultural word to find out what elements of culture involved then studied by using Baker's translation strategies for non-equivalence. The objectives of this analysis are to describe what categories of cultural word involved and what translation strategies are used. The result shows that the categories of cultural words are words or expressions referring to names of everyday objects, actions, and events, folklore, traditions, and mythology, geographic and ethnographic terms, social and historical terms denoting titles, while the translation strategies used are translation by using a loan word or loan word plus explanation, translation by paraphrase using a related word, translation by cultural substitution, and translation by omission.
\end{abstract}

Keywords - translation strategies; categories of cultural words; non-equivalence; The Land of Five Towers 'Negeri Lima Menara' ;Minangkabau cultural words

\section{INTRODUCTION}

The data source of this research is an Indonesian novel entitled Negeri Lima Menara, a novel written by A Fuadi, $25^{\text {th }}$ printing September 2016 with its translation 'The Land of Five Towers' $3{ }^{\text {rd }}$ printing May 2016 translated by Angie Kilbane. It is about a friendship among teenagers who study in a pesantren, an Islamic boarding school. With this theme, the novel involves words or terms related to Islam which means that it deals with Arabic language, Arabic words. And in this novel, the author exposes also the cultural background of the main character; Minangkabau culture. This automatically involves the use of Minangkabau cultural words, Minangkabau language; having direct equivalence as well as no direct equivalence (non-equivalence). The occurrence of Minangkabau cultural words in the novel may not as dominant as Islamic terms but the words have elaborated the cultural background of the main character, from the beginning till the end of the story. As the local language in Indonesia, Minangkabau language may not be widely informed to the world compared to Islamic terms in Arabic language, which means it is a challenging work to translate the Minangkabau cultural words not to mention the non-equivalence. The translator may need to find the equivalences in Indonesian language first then go on in English.

It becomes public knowledge that dealing with translation activities means dealing with at least two languages (the source language and the target language) as well as dealing with the cultures the languages bring along. The knowledge about the source language and the target language is as important as the knowledge about their cultures. The role of culture is so important that scholars believe that just a bilingual and bicultural translator is able to carry out a complete translation (Mashhady, Pourgalavi, \& Fatollahi, 2015). What happens in The Land of Five Towers 'Negeri Lima Menara', the involvement of the local language, Minangkabau language as a part of the source language requires a specific translation strategy that can solve the selecting of equivalences comprehensible for the readership of the target language text. As Baker's taxonomy of translation strategies is aimed to be applied in translating the nonequivalence at the word level and strengthened by the fact that they are used by professional translators, the strategies are used to view the translation of Minangkabau cultural words in this novel. What translation strategies are used and what category of cultural words occurred are the objectives of this research.

In doing this research, there are some related researches published in journals used as references either cited or noncited. The first one is entitled The Translation Strategies in Translating Balinese Cultural Words into English by Ria Saraswati, 2014, retrieved on March $29^{\text {th }}, 2018$, at 21:34 PM. 
She discusses three translation strategies by Baker (1992); translation by using loan words or loan words plus explanations which she divides into two subcategories; translation by using loan words (transference) and translation by using loan words plus explanations, translation by paraphrasing, and translation by cultural substitution (Saraswati, 2014). The similarities between Saraswati's research and this present research are that both use Baker's translation strategies, both discuss cultural words, and both involve the translation of literary work from Indonesian into English. The differences are on the number of strategies used, the local language used as non-equivalence cultural words, and the theory used for identifying the elements of culture in the culture. The second research is entitled The Application of Baker's Taxonomy on Translation of Literary Texts, A Case Study of George Orwell's Animal Farm by Amin Amir Dabbaghian \& Sanaz Solimary, published in 2013, retrieved on March $31^{\text {st }}, 2018$ at 21:30PM. This research uses Baker's taxonomy on the concept of equivalence; equivalence, grammatical equivalence, pragmatic equivalence, and textual equivalence (Dabbaghian \& Solimany, 2013) while this current research discusses Baker's taxonomy on the nonequivalence concept. Both researches use Baker's translation strategies, only this present research uses strategies for nonequivalence and their research uses Baker's strategies on equivalence. The next similarity is that both use literary works as the object but their work deals with English as the source language while this present research deals with English as the target language. The third research is entitled A Study of Main Character and Plot in Ahmad Fuadi's "Negeri Lima Menara" by Lapandja, Usman, Muhsin. The article was published in 2016 , retrieved at 20:30, March $29^{\text {th }}, 2018$. It is taken as one of the references because this article uses the same data source, a novel, Negeri Lima Menara. This research focuses on the main character of the novel, Alif Fikri; obedient to his parents, loyal to his friends, spirited, active boy, and religious, and the plot of the novel; the flash back plot (Lapandja \& Usman, 2016). They do not discuss the cultural background of the main character. On the other hand, this present focuses on it, Minangkabau culture as the cultural background of the main character in the novel. (Lapandja \& Usman, 2016). The fourth related research is A Model of Character Education as Reflected in Fuadi's "The Land of Five Towers" written by Hendra Darmawan and published in 2015. It was retrieved at 11:23 AM, April $1^{\text {st }}, 2018$. This article uses The Land of Five Towers the translated novel of Negeri Lima Menara as the source data and focuses on the students' character building in Pesantren Madani, the main setting of the novel. Darmawan mentions that in the pesantren students are formed to have the following noble characters; trustworthiness, respect, responsibility, caring, justice and leadership, humble/sincerity, solidarity, learning natural law (Darmawan, 2015). This research does not discuss the supportive elements involved in the main setting, the description of Minangkabau culture. The similarity between the research and this present research is on the data source, The Land of Five Towers. The difference between the two is that this present research uses both versions of the novel, the source text, Negeri Lima Menara and the target text, The Land of Five Towers. The last related research is entitled The Paradox of Islam and Culture
(Tradition and Belief about Gender Perspective in West Sumatra), by Reza Fahmi \&Prima Aswina. It is published in 2014 and retrieved at 23:30 PM, April $1^{\text {st }}$, 2018. This article deals with Minangkabau culture viewed by the psychological perspectives (Fahmi, Reza \& Aswirna, 2014). It is related to the present research as it discusses Minangkabau culture such as the function of its traditional house, Rumah Gadang, and it discusses also one of the important people and religious leaders in the history of the Minangkabau, Buya Hamka. The two things are parts of the cultural words discussed in the present research but without the psychological perspectives. These five articles are related to this present research, not to all the discussions but to one part or some.

\section{THEORETICAL REVIEW AND METHODOLOGY}

\section{A. Theoretical Review}

Translation strategy in Translation Studies has been defined in several ways based on how the scholars approach it, one of them is defined as pre-meditative methods for solving a problem which is faced in translating a text or any part of text (Hassan \& Tabassum, 2014). Translation strategies are either global or local; global strategies deal with translator's general principles and mode of action whereas local strategies deal with specific activities in relation to the translator's problem solving as well as decision-making (Saba \& Reza, 2016). We can conclude that translation strategy is needed when there is a problem. The translation strategies used to view the translation of Minangkabau cultural words in this research are categorized based on Mona Baker (2011): translation strategies used by professional translators dealing with nonequivalence at the word level. Baker's taxonomy of translation strategies includes the most applicable set of strategies because it shows the strategies which are used by professional translators (Owji, 2013).

Vazifehkhah quotes from Baker that non-equivalence at word level means that the target language has no direct equivalence for a word which occurs in the source text (Vazifehkhah, 2017, p. 102). This is what happened in the description of Minangkabau culture in the target text, some of Minangkabau cultural words have no direct equivalence. Baker (2011: 23-43) mentions that there are eight translation strategies used by professional translators for dealing with non-equivalence: translation by a more general word (superordinate), translation by a more neutral/lees expressive word, translation by cultural substitution, translation by using a loan word or loan word plus explanation, translation by [paraphrase using a related word, translation by paraphrase using unrelated word, translation by omission, and translation by illustration. Since the data found only deal with four strategies, the discussion here is limited only to these four; translation by cultural substitution, translation using a loan word or loan word plus explanation, translation by paraphrase using a related word, and translation by omission. The first strategy involves replacing a culture-specific item or expression with a target language item which does not have the same propositional meaning but is likely to have a similar 
impact on the target reader, for instance by evoking a similar context in the target culture (Baker, 2011, p. 29). The second is translation using a loan word or loan word plus explanation. This strategy is particularly common in dealing with culturespecific items, modern concepts and buzz word (Baker, 2011, p. 33). Translation using loan words plus explanations is a process of transferring SL word into TL word followed by explanation (Saraswati, 2014). The term loan word in this strategy is specified by Saraswati as a transference. The term transference itself is defined as the process of transferring a SL word to a TL text as a translation procedure (Newmark, 1988, p. 81). This strategy of translating using a loan word or loan words plus explanations makes the translated text more natural, more understandable and more familiar to the target reader (Owji, 2013). The third strategy is translation by paraphrase using a related word. This strategy tends to be used when the concept expressed by the source item is lexicalized in the target language but in a different form, and when the frequency with which a certain form is used in the source text is significantly higher than would be natural in the target language (Baker, 2011, p. 36). The fourth is translation by omission. This strategy may sound rather drastic, but in fact it does no harm to omit translating a word or expression in some contexts (Baker, 2011, p. 42). If the meaning conveyed by a particular item or expression is not necessary to mention in the understanding of the translation, translators use this strategy to avoid lengthy explanations (Owji, 2013).

Cultural elements (realia) which are identified in the data are viewed by Guerra. There are four major types of it (including objects, customs, habits, and other cultural and material aspects that have been impact in shaping a certain language) which can turn translation into a very difficult process; a) geographic and ethnographic terms, b) words or expressions referring to folklore, traditions and mythology, c) names of everyday objects, actions and events, such as food and drinks, clothes, housing, tools, public transport, dances and games, units of measurement, money, d) social and historical terms denoting territorial administrative units or divisions; professions, titles, ranks, greetings and treatments, patriotic and religious organizations (Guerra, 2012).

\section{B. Methodology}

This is a descriptive qualitative research as it includes surveys and fact-finding enquiries of different kinds and is concerned with qualitative phenomenon with the major purpose is to give a description of the state of affairs as it exists at present (Kothari, 2004). The qualitative method begins with collecting the description of Minangkabau culture involving cultural words and separating them based on the availabilities of their equivalences; using bilingual dictionaries; Indonesian - Minang, Minang - Indonesian, and Indonesian - English. After it is confirmed that the words have no direct equivalences, the next is to identify the cultural elements involved in each word based on Guerra's. Then as this research uses comparative approach the data in the source language are compared with the data in the target language to reveal what translation strategies are applied viewed by
Baker's translation strategies used by professional translators. The next procedure is to describe the finding and discussions relating to translation strategies applied as well as the category of cultural words.

\section{FINDINGS AND DISCUSSION}

There are only four translation strategies involved in translating the non-equivalence of Minangkabau cultural words found in the novel: Translation by Cultural Substitution, Translation by Using a Loan Word or Loan Word plus Explanation, Translation by Paraphrase Using a Related Word, and Translation by Omission. And for the category of cultural word, the non-equivalence found in the novel are identified as having cultural elements (realia): geographic term, ethnographic term, word or expression referring to folklore, word or expression referring to mythology, names of food, name of house, name of roof, and social and historical term denoting titles.

\section{A. Translation by Cultural Substitution}

There is only one data found regarding this strategy

\begin{tabular}{|c|l|c|}
\hline No. & Source Language Text & Target Language Text \\
\hline 1. & $\begin{array}{l}\text { "Tentang sekolah } \\
\text { waang, Lif..." (p. 6) }\end{array}$ & $\begin{array}{l}\text { "About your schooling, } \\
\text { son..." (p. 6) }\end{array}$ \\
\hline
\end{tabular}

The word waang is a non-equivalence; it has no direct equivalence either in Indonesian or in English. What strengthens the position of this word non-equivalence is that this specific pronoun does not exist both in Indonesian and in English. Seeing from the major types of realia (cultural element) the word is an ethnographic term as it is taken from Minangkabaunese which is used to call a male addressee, younger than the speaker in a non-formal dialog. Waang can be translated into 'kamu' in Indonesian or 'you' in most context when the speaker is older than the addressee or having more power than the addressee in a condition that the addressee has to be a male. This cannot be applied to female addressee.

In the novel the word waang is translated into 'son', it is a cultural word referring to a male child in English. The meaning may not be perfectly similar as waang is used for all male addressees in Minangkabau culture who are younger than the speaker but the context of the dialog, a dialog between a mother and her son, makes this equivalence acceptable. The semantic components contained in the word waang and son are almost the same; both refer to male addressee, younger than the speaker. Therefore the strategy used for translating the word waang is translation by cultural substitution. The translator may assume that the readership of the target language may not need any detail information regarding to this term so no explanation needed there. 


\section{B. Translation by Using a Loan Word or Loan Word Plus Explanation}

There are four data regarding this strategy; three data are Loan Words plus Explanations and one is Loan Word only with no explanation.

\begin{tabular}{|c|l|l|}
\hline No. & Source Language Text & \multicolumn{1}{|c|}{ Target Language Text } \\
\hline 2. & $\begin{array}{l}\text {.. dan sebungkus } \\
\text { rendang kapau yang } \\
\text { sudah kering kehitam- } \\
\text { hitaman. (p. 14) }\end{array}$ & $\begin{array}{l}\text {.. and a package of } \\
\text { dried, blackish rendang- } \\
\text { spicy meat. (p. 14) }\end{array}$ \\
\hline
\end{tabular}

The cultural word rendang is a non-equivalence or having no direct equivalence as it is so specific to refer to a name of food originally comes from Padang or Minangkabau culture. It is meat cooked with coconut milk and various ingredient until it is dried and blackish therefore the process of cooking it takes a long time and intended not to be consumed in one time meal. Usually it is spicy or even hot. In this context, the word kapau is added directly after the word rendang so it becomes rendang kapau. This indicates some meanings that it may refer to a kind of rendang which is made in Kapau, a name of a place in West Sumatra under the area of Minangkabau culture, or it can refer to the rendang made by people from Kapau, or it can refer to the rendang made by anybody using a Kapau recipe. Seeing from the cultural elements involved, rendang kapau is a part of names of everyday objects, actions, and events; food.

It is translated into just 'rendang' as a loan word without the name kapau. The strategy which is used in translating this words rendang kapau is identified as the strategy of translation using a loan word or loan word plus explanation. The word rendang is taken to the target language text as a loan word rendang and it is added by an explanation in a short phrase 'spicy meat'. The readership of the target language will get the complete information that there is this specific food in Minangkabau culture, spicy meat by the name of rendang.

\begin{tabular}{|c|l|l|}
\hline No. & Source Language Text & \multicolumn{1}{|c|}{ Target Language Text } \\
\hline 3. & .. bus kecil Harmonis & .. a small Harmonis bus \\
& yang terkentut-kentut & that sputtered along a \\
& merayapi Kelok Ampek & notorious road called \\
& Puluah Ampek. (p. 15) & $\begin{array}{l}\text { Kelok Ampek Puluah } \\
\text { Ampek. (p. 15) }\end{array}$ \\
\hline
\end{tabular}

The cultural word Kelok Ampek Puluah Ampek is one of the non-equivalence to refer to a geographic condition in a certain location of Minangkabau area. It is a name of a road that has forty four sharp turns not created deliberately by human being but it adopts to the geographic condition of the location. Seeing from the category of cultural word, this term is identified as a cultural word of geographic term as it refers to a road climbing up the mountain above Maninjau Lake with forty four 'ampek puluah ampek' turns 'kelok'.

The term is translated using the strategy of Translation Using a Loan Word or Loan Word plus Explanation. It is taken to the target language text as a loan word or transference Kelok Ampek Puluah Ampek. These forty four turns are so sharp that cause many accidents and deaths. The translator has the knowledge of this so she chooses to add the loan word Kelok Ampek Paluah Ampek with explanation; notorious road. The readership of the target language text will get the details about these forty four sharp turns called Kelok Ampek Puluah Ampek located in West Sumatra.

\begin{tabular}{|c|l|l|}
\hline No. & \multicolumn{1}{|c|}{ Source Language Text } & \multicolumn{1}{|c|}{ Target Language Text } \\
\hline 4. & .. sebagai kota asal & .. as the hometown of \\
& $\begin{array}{l}\text { Buya Hamka, ulama } \\
\text { sastrawan karismatik } \\
\text { yang tersohor itu. (p. 43) }\end{array}$ & $\begin{array}{l}\text { renowned charismatic } \\
\text { cleric and writer. (p.41) }\end{array}$ \\
\hline
\end{tabular}

The cultural word Buya that is attached to a name Hamka is categorized as a non-equivalence. It is not a part of the given name of Hamka. Seeing from its element of culture, it is identified as social and historical terms; specifically titles. It is given to a respectful religious leader of an Islamic organization in Minangkabau culture. Hamka who happens to be an Indonesian well-known writer is one of them. The term Buya is only given to Minangkabau people.

The strategy used is Translation by Using a Loan Word or Loan Word plus Explanation, only this time it is not plus explanation. The word Buya attached to the name Hamka is taken as loan word to the target language text. The explanation the renowned charismatic cleric and writer after the Buya Hamka is not intentionally added by the translator; it is there given by the author, the translator just translates it. Therefore it is not included into the strategy of Loan Word plus Explanation, it is just the strategy of Translation Using a Loan Word. The readership of the target language may not know that Buya is not a part of the name, it is a titles.

\begin{tabular}{|c|l|l|}
\hline No. & Source Language Text & \multicolumn{1}{|c|}{ Target Language Text } \\
\hline 5. & $\begin{array}{l}\text { Kenapa hatiku begitu } \\
\text { keras? Aku tidak mau } \\
\text { menjadi Malin Kundang } \\
\text { yang menjadi batu karena } \\
\text { melawan ibunya. } \\
\text { (p. 142) }\end{array}$ & $\begin{array}{l}\text { Why was my heart so } \\
\text { hard? I didn't want to } \\
\text { become like the boy in } \\
\text { the folktale, Malin } \\
\text { Kundang, who was } \\
\text { turned to stone by } \\
\text { opposing his mother. (p. } \\
133)\end{array}$ \\
\hline
\end{tabular}

Malin Kundang in the context is not just an ordinary name. The author uses this name to indicate a very popular character in Minangkabau folklore. It is a non-equivalence as it is a name. Seeing from the category of cultural words Malin Kundang is identified as having cultural elements of words or expressions referring to folklore. The folklore is closely related to the matrilineal system of Minangkabau culture; about the role of a woman, a mother. They are a very poor family. Her son, Malin Kundang, after leaving his home town for quite sometimes, gets married with a very rich lady, he owns a big ship and comes home. Unfortunately he is too embarrassed to admit that the old poor lady who has been 
waiting for him with so much love to him in his home town is his own mother. He ignores his own mother. So painful with his behaviour, his mother curses him to become a stone. Maling Kundang and all passengers in the ship including the ship itself are turned into a stone.

The strategy used is Translation Using a Loan Word or Loan Word plus Explanation. The translator adds the loan word Malin Kundang with an explanation, "the boy in the folktale", to give local culture of the source language to the target language text. By doing this, the readership of the target language text will get the idea of who Malin Kundang is. That Malin Kundang which is in the text is a name of a character in a folklore of Minangkabau culture.

\section{Translation by Paraphrase Using a Related Word}

\begin{tabular}{|c|c|l|}
\hline No. & Source Language Text & \multicolumn{1}{|c|}{ Target Language Text } \\
\hline 6. & $\begin{array}{c}\text { Bunyi talempong segera } \\
\text { membahana,...” (p. 17) }\end{array}$ & $\begin{array}{l}\text { The sound of } \\
\text { traditional Minang } \\
\text { music would soon } \\
\text { thunder,...” (p. 17) }\end{array}$ \\
\hline
\end{tabular}

The cultural word talempong is a non-equivalence as it is the name of traditional music in Minangkabau culture. It is so specific that it produces a very unique sound that cannot be produced similarly by any other music. This music has been created in Minangkabau culture for a long time and is usually used as the music of traditional art performance, like dances, silek, Indonesian traditional martial arts. The term talempong can refer to the instrument, the ensemble or to the genre of music. Seeing from the category of cultural words, the word talempong is identified as having the elements of culture; names of everyday objects, actions and events; a name of music. It is translated into 'traditional Minang music'.

The strategy used in translating the word talempong is translation by paraphrase using a related word. The cultural word talempong is not transferred as a loan word into the target language text. It is simply paraphrased into 'traditional Minang music'. The key word that relates the talempong and traditional Minang music is the word music. The translator chooses not to use the cultural word as a loan word therefore the readership of the target language text will only know that Minangkabau culture has its own traditional music yet they will not know what the name of the music is.

\begin{tabular}{|c|l|l|}
\hline No. & Source Language Text & \multicolumn{1}{|c|}{ Target Language Text } \\
\hline 7. & $\begin{array}{l}\text { Berbeda dengan atap } \\
\text { rumah gadang yang } \\
\text { menyerupai tanduk dan } \\
\text { lancip di kiri dan kanan, } \\
\text { atap di sini lancip di } \\
\text { tengah. (p. 28) }\end{array}$ & $\begin{array}{l}\text { Different from the } \\
\text { traditional houses in } \\
\text { Minang which look like a } \\
\text { pair of horns peaking at } \\
\text { both sides, the roofs here } \\
\text { peaked at the center. (p. } \\
27)\end{array}$ \\
\hline
\end{tabular}

The cultural words rumah gadang is a non-equivalence which refers to a very well-known cultural term regarding the traditional house in Minangkabau culture. In Indonesian it is known as "rumah adat" of the Minangkabau. The architecture, construction, internal and external decoration, and the functions of the house reflect the culture and values of the Minangkabau. A rumah gadang serves as a residence, a hall for family meetings, and for ceremonial activities. Seeing from the category of cultural word, the term belongs to the category of names of everyday objects, actions and events; a building or a house.

It is translated into 'the traditional houses in Minang' applying the strategy of translation by paraphrase using a related word. The related word in this context is houses. The translator does not use the term as a loan word instead she just paraphrases it. At least the readership of the target language will know that there is a traditional house in Minangkabau culture but the name of it will not be revealed.

\begin{tabular}{|c|c|c|}
\hline No. & Source Language Text & Target Language Text \\
\hline 8. & $\begin{array}{l}\text {... dan } \text { katan jo } \\
\text { karambia } \text { sajian } \\
\text { Amak,...(p. } 88 \text { ) }\end{array}$ & $\begin{array}{l}\text {.... and sticky steamed } \\
\text { rice mixed with coconut } \\
\text { meat and sugarcane from } \\
\text { Amak... (p. 82) }\end{array}$ \\
\hline
\end{tabular}

The word katan jo karambia 'ketan dan kelapa' is a name of everyday snack in Minangkabau culture. People eat this food usually in the morning after breakfast or for breakfast. There are two cultural words combined together in the term; katan and karambia both of them refer to food. It refers to one kind of food not two as its names. The process of how to make it is not reflected through the name.

The term katan jo karambia is translated using the strategy of translation by paraphrasing with a related word. Katan is translated into a phrase 'sticky steamed rice' while karambia which means 'coconut' is translated into the phrase 'coconut meat' which is actually 'grated coconut meat'. With only 'coconut meat' used as the equivalent for karambia, the readership of the target language text will have no idea how coconut meat is mixed with sticky steamed rice. The translator adds the two expressions with 'and sugarcane' as the footnote in the source language text says so. The readership of the target language may not be able to figure it out how the food is made or served but at least they get the idea what the food consists of.

\section{Translation by Omission}

\begin{tabular}{|c|l|l|}
\hline No. & Source Language Text & \multicolumn{1}{|c|}{ Target Language Text } \\
\hline 9. & $\begin{array}{l}\text { Sebuah menara jam } \\
\text { besar dengan puncak } \\
\text { berbentuk atap } \\
\text { bagonjong-atap } \\
\text { tradisional Minang yang } \\
\text { berbentuk tanduk } \\
\text { kerbau. (p. 95) }\end{array}$ & $\begin{array}{l}\text { It's a big clock tower with } \\
\text { its top resembling a } \\
\text { traditional Minang roof } \\
\text { shaped like buffalo horns. } \\
\text { (p. 89) }\end{array}$ \\
\hline
\end{tabular}


The word bagonjong is a non-equivalence as it has no direct equivalence either in Indonesian or in English. It is a name of roof in Minangkabau culture which refers to a shape of roof in its traditional house. Now it is used as an identity not limited to the traditional house called rumah gadang but in Minangkabau restaurants in West Sumatra and also in other places around the world. Seeing from its category, it has the elements of culture; names of everyday objects, actions and events; roof.

The term bagonjong is not used as a loan word in the target language text; it is just simply omitted. The translator may think that the term bagonjong is not necessary anymore as the explanation about it is already there, given by the author. The translator just needs to translate it. The readership of the target language text may not know the name of the traditional roof with the unique shape, the shape of buffalo water horns in Minangkabau culture but they will get the information about the shape of this unique roof. The strategy of translation by omission is acceptable in this case.

\begin{tabular}{|c|l|l|}
\hline No. & Source Language Text & \multicolumn{1}{|c|}{ Target Language Text } \\
\hline 10. & $\begin{array}{l}\text { Menurut legenda, } \\
\text { inyiak, atau harimau } \\
\text { dianggap adalah } \\
\text { peliharaan yang patuh } \\
\text { kepada orang-orang } \\
\text { yang sakti di Minang (p. } \\
\text { 375) }\end{array}$ & $\begin{array}{l}\text { According to legend, } \\
\text { inyiak are the pets of } \\
\text { sacred Minang people. (p. } \\
\text { 353) }\end{array}$ \\
\hline
\end{tabular}

The cultural word inyiak is a non-equivalence as it does not refer to its literal meaning which is equivalent to grandfather 'kakek'. People of Minangkabau culture believe that mentioning the word 'harimau' is taboo. They still believe that this animal has an ability to hear 'earth ear' or 'telinga bumi' that wherever people mention its name 'harimau', the animal could hear it. They believe also that this animal is very often owned by the Minangkabau sacred people who has a power to heal others. People there do not want to get involved with this animal especially when they are in the jungle or near the jungle. By not mentioning its name can be considered as taking a wise and safe way. When they need to say the name of this animal, they will usually automatically use the term 'inyiak' instead. Seeing from the category of cultural word, the cultural word inyiak is categorized as the words or expressions referring to mythology.

The strategy used is translation by omission. It needs to be clarified that what is omitted here is not the cultural word inyiak but the information related to the word as mentioned by the author in the source language text about what is inyiak; tiger. That inyiak in the Minangkabau mythology is a tiger, people believe it is a stealth tiger. It is very loyal or dedicated to its master. The master is believed to be the sacred Minang people. The translator omits the key word 'tiger' and the word 'loyal or dedicated' therefore the information received by the readership of the target language is just the general idea about what the myth is all about that they are pets of sacred Minang people. Compared to the previous case of omission on the word bagonjong where the whole description about the word bagonjong is kept, the omission of the word tiger as a part of the description on inyiak may give different impact. The readership of the target language will have no idea what kind of pets discussed in the novel. The message that the author would like to share about inyiak is not completely transmitted in the target language text.

\section{CONCLUSION}

The occurrences of the non-equivalence of cultural words in the novel are more than what are discussed in this research which means that not all of them can be viewed by using Baker's taxonomy of translation strategy used by professional translators for non-equivalence at a word level. One of the reasons is because the cultural words found in the novel have already been provided by explanations by the author, either in the form of footnotes or additional information such as explanations and paraphrases. For future research, it is recommended to any scholar who is interested with this subject to view this case using other translation strategies.

Based on what can be seen in the findings and discussions it can be concluded that

- Most of Minangkabau non-equivalence cultural words found in the novel The Land of Five Towers 'Negeri Lima Menara' have the elements of culture; names of everyday objects, actions and events ranging from names of food, names of house, names of building (roof), to names of music.

- Although the non-equivalence of Minangkabau cultural words belong to the same category of cultural words, having the same cultural elements; names of everyday objects, actions, and events, not all of them are translated using the same translation strategy.

- Mostly the strategies used in the novel are Translation by Using Loan Word or a Loan Word plus Explanation followed by Translation by Paraphrase Using a Related Word.

- Very possibly the reason why Translation by Using Loan Word or a Loan Word plus Explanation is preferable because by using this strategy, the translator has a chance to accommodate the complete information regarding the cultural words which have no direct equivalent in the target language.

$\square$

\section{Acknowledgment}

This research is a part of HIU (Hibah Internal Unpad) 2017 Research, funded by Universitas Padjadjaran. Publications through journals both nationally and internationally are the major aims which are required.

\section{References}

Baker, M. (2011). In other words: A coursebook on translation, second edition. In other words: A coursebook on translation (3rd ed.). Routledge Taylor and Francis Group.

Dabbaghian, A. A., \& Solimany, S. (2013). The application of Baker's 
taxonomy on translation of literary texts, A Case Study of George Orwell's Animal Farm. International Journal of Science and Research (IJSR), 2(12), 280-284.

Darmawan, H. (2015). A Model of character education as Reflected in Fuady ' $s$ the Land of Five Towers. International Journal on Studies in English Language and Literature (IJSELL) Volume 3, Issue 8, August 2015, 3(8), 16-22.

Fahmi, Reza \& Aswirna, P. (2014). The paradox of Islam and culture ( tradition and belief abot gender perspective in West Sumatra ). A Turas, $X X(2), 313-324$. Retrieved from http://journal.uinjkt.ac.id/index.php/alturas/article/download/3763/2757

Guerra, F. A. (2012). Translating culture: problems, strategies and practical realities. [Sic] - a Journal of Literature, Culture and Literary Translation, (1.3), 1-27. https://doi.org/10.15291/sic/1.3.lt.1

Hassan, \& Tabassum. (2014). Strategies of Translating Idioms. British Journal of English Linguistics, 2(3), 14-29.

Kothari, C. R. (2004). Research Methodology_Methods and Techniques. Jaipur: New Age International Publishers.

Lapandja, F. K. D., \& Usman, S. (2016). A Study of Main Character and Plot in Ahmad Fuadi's "Negeri 5 Menara," 4(1), 1-13.

Mashhady, H., Pourgalavi, M., \& Fatollahi, M. (2015). Newmark's Procedures in Persian Translation of Golding's. International Journal of English Language \& Translation Studies. 3(1), 57-69. Retrieved from Http://Www.Eltsjournal.Org, 3, 57-69.

Newmark. (1988). A Textbook of Translation (1st ed.). Prentice Hal International (UK) Ltd.

Owji, Z. (2013). Translation Strategies: A Review and Comparison of Theories. Translation Journal, 17(1). Retrieved from http://translationjournal.net/journal/63theory.htm

Saba, A., \& Reza, K. (2016). A Review on Translation Strategies of "Little Prince." International Journal of English Language \& Translation Studies, 4(3), 60-68

Saraswati, R. (2014). The Translation Strategies in Translating Balinese Cultural Words into English. Journal of English Language and Culture, 4(2), 110-119. Retrieved from http://journal.ubm.ac.id/index.php/english-languageculture/view/323/310

Vazifehkhah, A. E. (2017). Non-Equivalence at Idiomatic and Expressional Level and the Strategies to Deal with : English Translation into Persian, (2010), 31-37. 